\title{
A comparison of digestibility coefficients of nutrients in horse feeds as determined by conventional and lignin methods
}

\author{
Jadwiga Chachułowa', J. Lojek' ${ }^{2}$, S. Chrzanowski², \\ J. Chachuła ${ }^{2}$ and J. Stróżewski ${ }^{1}$ \\ 'Department of Animal Nutrition and Feed Management, \\ - Department of Animal Breeding. \\ Warsaw Agricultural University \\ Rakowiecka 26/30, 02-528 Warsaw, Poland
}

(Received 27 April 1994: accepted 14 September 1994)

\begin{abstract}
Nutrient and energy digestibility of feeds were determined in four experiments on saddle horses by both the conventional and lignin methods. The following fecds were analysed; mcadow hay plus oats; meadow hay; meadow hay plus triticale and pasture forage. Similar digestibility coefficients of nutrients in the meadow hay-oats ration were obtained by both methods. The differences in these coefficients in the hay-triticale and meadow hay rations were greater and fat digestibility in these feeds was negative. The greatest differences were found for the forage ration.

Lignin recovery from faeces ranged from 98 to $101 \%$ for grain - hay and hay rations, and only $87 \%$ when forage was fed.
\end{abstract}

KEY WORDS: horses, digestibility, lignin method

\section{INTRODUCTION}

In studies on the nutritive values of horse feeds, no satisfactory indicator method has yet been developed to determine digestibility coefficients in horses allowed freedom of movement. Fuchs et al. (1992) and Zeyner et al. (1992) used $4 \mathrm{~N} \mathrm{HCl}$ insoluble ash as an indicator. In our earlier experiments (Chachułowa et al., 1993) we added chromic oxide or cellite to horse feed, which increased the amount of insoluble ash in the ration and digestibility indexes were determined in relation to them. $\mathrm{Cr}_{2} \mathrm{O}_{3}$ was found to be unsuitable since it was very difficult to 
mix evenly with feeds like hay and oats. Because the results were unsatisfactory, an attempt was made to use lignin, a natural component of feeds, as an indicator.

The objective of the study was to compare the digestibility coefficients of nutrients and energy determined by conventional and lignin methods in feeds given to horses.

\section{MATERIAL AND METHODS}

The experiment was conducted over 4 feeding periods on 4 to 6 half-breed gildings aged 6 to 8 years weighing about $560 \mathrm{~kg}$. The horses were fed 3 times daily $(7.00 \mathrm{am}, 1 \mathrm{pm}$ and $6 \mathrm{pm})$, with equal portions of their daily ration. The composition and amount of feeds are given in Table 1 . The faeces collection period lasted 6 days and was preceded by a 7-10 day preliminary period. The horses were kept in stables with smooth concrete floors from which the faeces were collected. The daily portions of faeces from each horse were thoroughly mixed and 10\% aliquots taken and conserved in chloroform. The conserved samples were stored in the refrigerator until the end of the collection period when all of the samples from each horse were mixed and the fresh matter nitrogen content was determined. The remaining part of the sample was partly dried at $60^{\circ} \mathrm{C}$ and used for assay of the remaining nutrients. In order to assess the differences in the amount of lignin excreted with the faeces during the day, samples were taken in the morning (8.00 AM) and evening (6.00 PM) in the second and third period of study.

The chemical composition of the feeds and faeces were determined by conventional methods; lignin according to Van Soest (1973); gross energy using a $\mathrm{K}-10$ calorimeter.

The results were analysed statistically using single factor analysis.

\section{RESULTS}

The chemical composition of the feeds is given in Table 1. The composition of the hay fed during the first period was the equivalent of meadow hay from the first cut at ear emergence (Nutrient Requirements of Horses, 1991). The quality of the meadow hay during the successive feeding periods was worse since it was harvested after grasses had flowered.

The digestibility coefficients of nutrients determined in the first period for the hay-oats feed were greater than for the remaining feeds and the best consistency between results as determined by the conventional and lignin methods was found. The digestibility of the nutrients in the hay-triticale feed was worse and the results of both tested methods were not as consistent. During the second period when meadow hay was the sole feed, digestibility coefficients were 


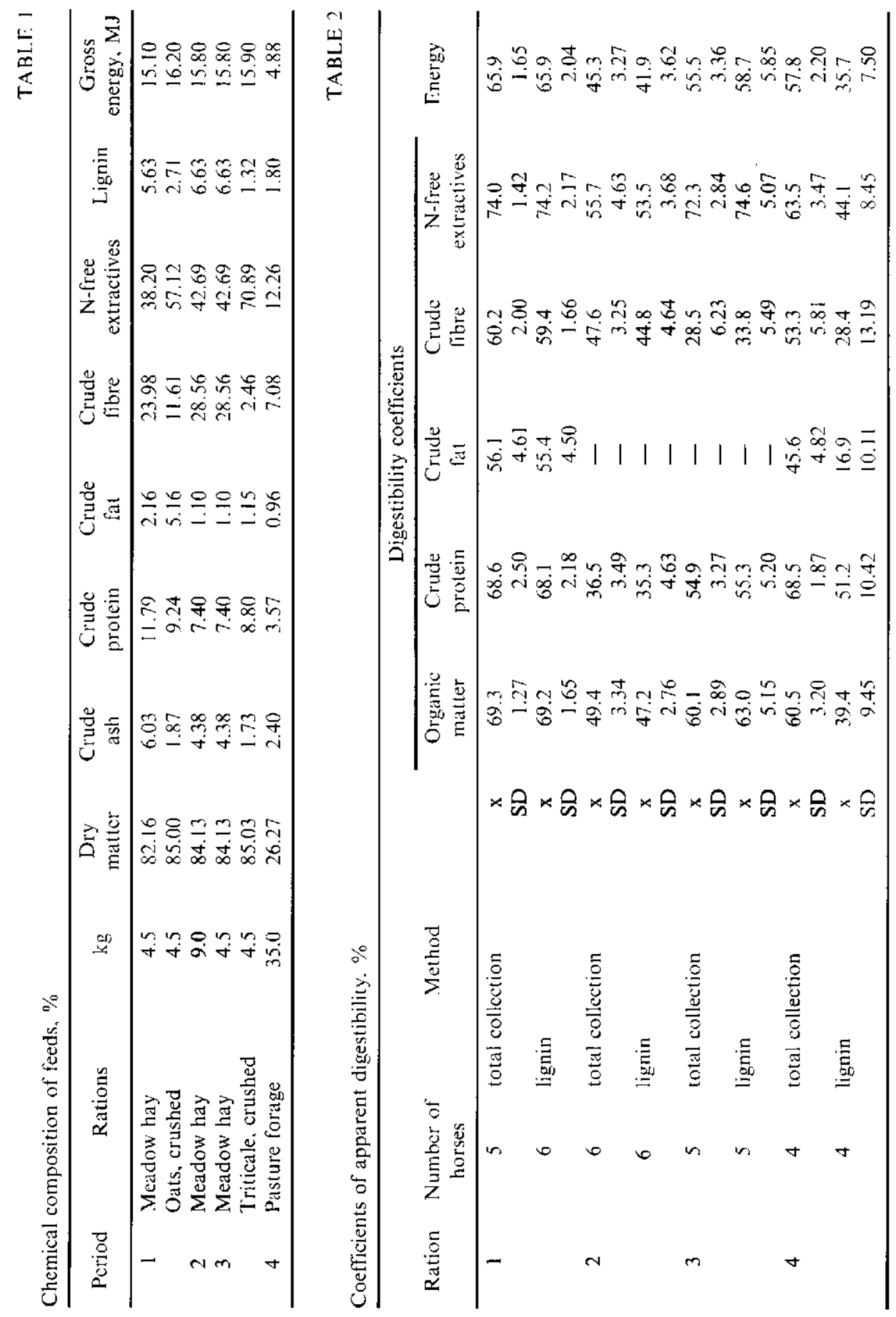


TABLE 3

Recovery of lignin in the faeces, $\%$

\begin{tabular}{cccc}
\hline Period & Number of horses & Recovery of lignin, \% and SD \\
1 & 6 & 98.8 & \pm 1.02 \\
2 & 6 & 98.0 & \pm 2.50 \\
3 & 5 & 101.0 & \pm 2.30 \\
4 & 4 & 86.7 & \pm 9.02 \\
\hline
\end{tabular}

TABLE 4

Content of lignin in the faeces of horses, \%

\begin{tabular}{|c|c|c|c|c|}
\hline \multirow{3}{*}{ Horse } & \multicolumn{4}{|c|}{ Lignin. $\%$} \\
\hline & \multicolumn{2}{|c|}{ period 2} & \multicolumn{2}{|c|}{ period 3} \\
\hline & $8^{00}$ & $18^{(30)}$ & $8^{5010}$ & $18^{00}$ \\
\hline A & 3.57 & 4.20 & 4.30 & 4.25 \\
\hline B & 3.08 & 3.62 & 2.69 & 3.39 \\
\hline $\mathrm{C}$ & 3.74 & 3.24 & 3.45 & 3.30 \\
\hline $\mathrm{D}$ & 3.07 & 3.30 & 2.74 & 2.91 \\
\hline $\mathrm{x}$ & 3.36 & 3.59 & 3.29 & 3.46 \\
\hline SD & \pm 0.342 & +0.439 & \pm 0.754 & \pm 0.565 \\
\hline
\end{tabular}

considerably lower. During these first three periods the correspondence between the digestibility coefficient as determined by both methods was more or less satisfactory. During the fourth period when pasture forage was fed as the sole feed, the mean digestibility coefficients as determined by the conventional method were 21.1 units higher for organic matter, 17.3 units for crude protein, 28.7 units for raw fat, 24.9 for raw fibre, 19.4 for $\mathrm{N}$-free extractives and 22.1 for energy than estimated by the lignin method.

Fat digestibility in the diet composed exclusively of hay or of hay with triticale was zero or negative.

Significant individual differences in digestibility coefficients were found among horses, especially when they were fed forage.

Between periods 1 to 3 , i.e. when the hay-oats, hay and hay-triticale rations were fed, lignin recovery from faeces ranged from 98 to $101 \%$; when forage was fed, recovery was only about $87 \%$ (Table 3 ).

No major differences were found between the average lignin content in faeces samples collected in the morning and evening (Table 4).

Table 5 presents the nutritive value of the rations calculated on the basis of the chemical composition of the feeds and digestibility coefficients determined using the conventional and lignin methods. 


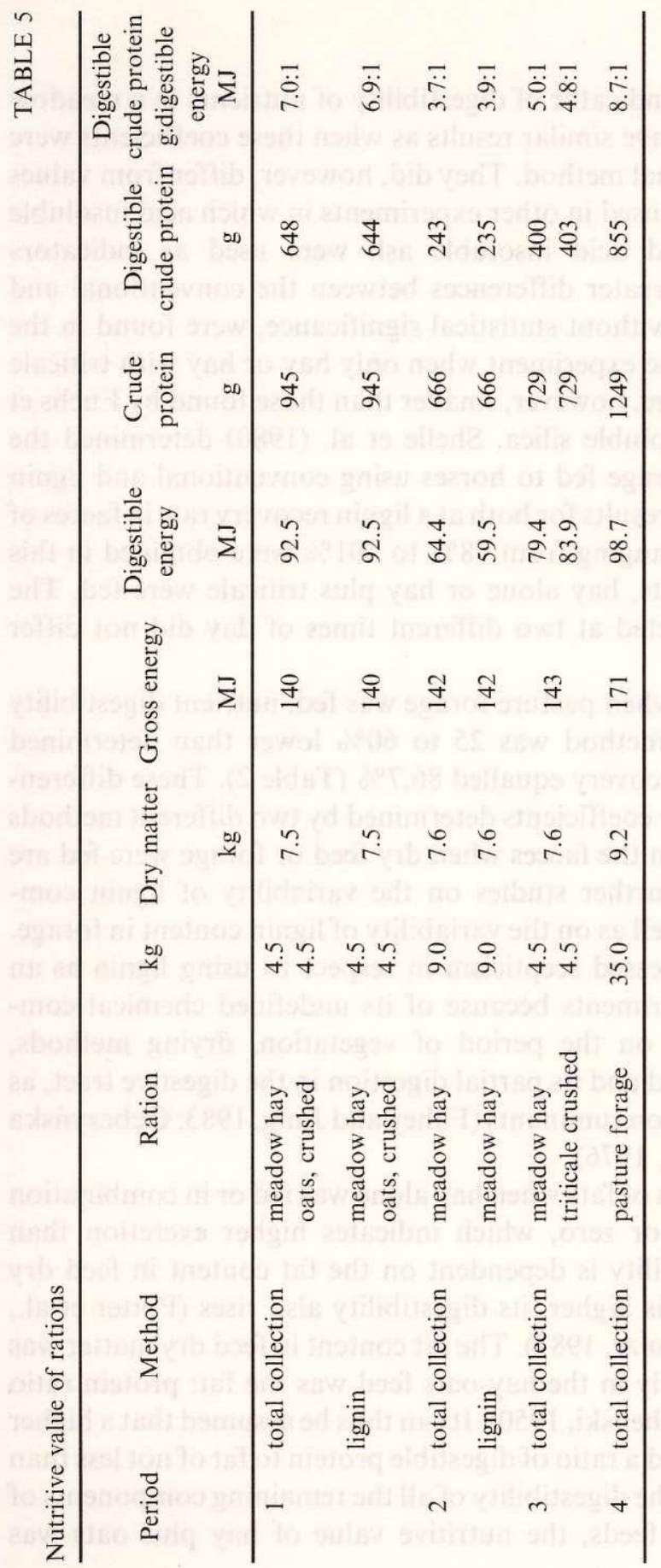




\section{DISCUSSION}

Lignin used as an internal indicator of digestibility of nutrients in a meadow hay-oat feed given to horses gave similar results as when these coefficients were determined using a conventional method. They did, however, differ from values determined in a similar ration used in other experiments in which acid insoluble silica added to the feed and acid insoluble ash were used as indicators (Chachułowa et al., 1993). Greater differences between the conventional and indicator methods, although without statistical significance, were found in the second and third periods of the experiment when only hay or hay with triticale were fed. These differences were, however, smaller than those found by Fuchs et al. (1987), who used acid-insoluble silica. Shelle et al. (1980) determined the digestibility of nutrients in forage fed to horses using conventional and lignin methods and obtained similar results for both at a lignin recovery rate in facces of $98 \%$. Similar recovery rates ranging from $98 \%$ to $101 \%$ were obtained in this experiment when hay plus oats, hay alone or hay plus triticale were fed. The lignin content of faeces collected at two different times of day did not differ significantly (Table 4).

During the fourth period, when pasture forage was fed, nutrient digestibility as determined by the lignin method was 25 to $60 \%$ lower than determined conventionally, while lignin recovery equalled $86.7 \%$ (Table 2 ). These differences in the values of digestibility coefficients determined by two different methods and in the recovery of lignin in the faeces when dry feed or forage were fed are difficult to explain without further studies on the variability of lignin composition and digestibility, as well as on the variability of lignin content in forage. Other authors have also expressed scepticism in respect to using lignin as an indicator of digestibility experiments because of its undefined chemical composition and its dependence on the period of vegetation, drying methods, degradability when quantitated and its partial digestion in the digestive tract, as has been found in experiments on ruminants (Fahey and Jung, 1983; Gębcryńska et al., 1974; Kowalczyk et al., 1976).

The digestibility coefficients of fats when hay alone was fed or in combination with triticale, were negative or zero, which indicates higher excretion than ingestion of fats. Fat digestibility is dependent on the fat content in feed dry matter; when the fat content is higher, its digestibility also rises (Potter et al., 1992; Sallman et al., 1992; Schulze, 1987). The fat content in feed dry matter was $1.5 \%$ in the studied feeds. Only in the hay-oats feed was the fat: protein ratio optimal, equalling 1:3 (Prawocheński, 1950). It can thus be assumed that a higher energy content of the ration and a ratio of digestible protein to fat of not less than 3:1 has a favourable effect on the digestibility of all the remaining components of the diet. Among the studied feeds, the nutritive value of hay plus oats was 
highest, and its protein : energy ratio was close to the values given in Nutrient Requirements of Horses (1991).

Naturally occurring lignin was found to be suitable for determining digestibility coefficients in horse feeds composed of hay, hay plus oats or hay plus triticale. When forage was given, however, lignin was unsuitable as an indicator. Its recovery in faeces was only $87 \%$ and digestibility coefficients were much lower than determined using the conventional method. Further studies are needed to explain this observation.

\section{REFERENCES}

Chachułowa J., Stróżewski J., Chrzanowski S., Łojek J., 1993. The comparison of digestibility of feeds in horses determined by the classic and index methods. Ann. Warsaw Agric. Univ. SGGW, Anim. Sci. 29, 67-72

Fahey G.C., Jung H.G., 1983. Lignin as a marker in digestion studies: a reviev J. Anim. Sci. 57, 220-225

Fuchs R., Militz H., Hoffmann M., 1987. Untersuchungen zur Verdaulichkeit der Rohnährstoffe bei Pferden. Arch. Tierernähr. 37, 235-246

Fuchs R., Kaske H., Hoffmann M., Zeyner A., 1992. Untersuchungen zum Einfluss von Knaulgrasmund und Maissilage als Rationskomponenten auf die Verdaulichkeit der Rohnärstoffe beim Reitpferd. Pferdeheilkunde. 1. Europäische Konferenz über die Ernährung des Pferdes. Institut f. Tierernähr. Tierärztliche Hochschule, Hannover, 165-168

Gębczyńska Z., Kowalczyk J., Krasińska M., Ziołecka A., 1974. A comparison of the digestibility of nutrients by European bison and cattle. Acta theriol. 19, 283-289

Kowalczyk J., Gębczyńska Z., Krasińska M., 1976. The digestibility of nutrients of natural diet by European bison in different seasons. Acta theriol. 21, 141-146

Nutrient Requirements of Horses (in Polish), 1991. Publ. of The Kielanowski Institute of Animal Physiology and Nutrition, Jabłonna, Poland

Potter G.D., Hughes S.L., Julen T.R., Swinney D.L., 1992. A review of research on digestion and utilization of fat by the equine. Pferdeheilkunde. 1. Europäische Konferenz über die Ernährung des Pferdes. Institut f. Tierernähr. Tierärztliche Hochschule, Hannover, 119-123

Prawocheński R., 1950. Horse breeding (in Polish). Vol. III. PWRiL, Warszawa

Sallmann H.P., Kienzle E., Fuhrmann G., Grunwald D., Eilmans I., Meyer H., 1992. Einfluss einer marginalen Fettversorgung auf Fettverdaulichkeit, Lipidgehalt und - zusammensetzung von Chymus. Gewebe und Blut. Pferdeheilkunde. 1 Europäische Konferenz über die Ernährung des Pferdes. Institut f. Tierernähr. Tierärztliche Hochschule, Hannover, 124-127

Schulze K., 1987. Untersuchungen zur Verdaulichkeit und Energiebewertung von Mischfutter-mitteln für Pferde. Dissertation. Tierärztliche Hochschule, Hannover, 1-131

Shelle J.E., Whetter P.A., Ullrey D.E., 1980. Fresh forage digestion by horses using total collection or lignin indicator. J. Anim. Sci. 51, Suppl. 1, 221, abstr. 283

Sobczak Z., Formicka E., 1979. Urea as a supplement of protein deficiency ration for horses. I. Digestibility of feeds with urea by working horses. II. Digestibility of feeds with urea by saddle horses. Zesz. Nauk. AR Wrocław 121, Zoot. 22, 79-87, 89-100 
Van Soest P.J., 1973. Collaborative study: acid detergent fiber and lignin. J. Assoc. Off. Anal. Chem. $56,781-784$

Zeyner A., Hoffmann A., Fuchs R., 1992. Möglichkeiten zur Schätzung des Energie - gehaltes in Rationen zur Sportpferdefütterung. Pferdeheilkunde. 1. Europäische Konferenz über die Ernährung des Pferdes. Institut f. Tierernähr. Tierärztliche Hochschule, Hannover, 175-178

\section{STRESZCZENIE}

\section{Porównanie współczynników strawności pasz dla koni oznaczonych metodą ligninową i klasyczną}

W czterech doświadczeniach strawnościowych na 4 lub 6 koniach użytkowanych wierzchowo o masie ciała około $560 \mathrm{~kg}$ oznaczono strawność składników pokarmowych i energii metodą klasyczną i ligninową następujących dawek: siano łąkowe z owsem, siano łąkowe, siano łąkowe z pszenżytem i zielonka pastwiskowa.

Otrzymano zbliżone współczynniki strawności składników pokarmowych dawki siano-owies przy zastosowaniu obydwóch metod. Większe różnice były we współczynnikach strawności zestawu siano-pszenżyto i siano łąkowe. W dwóch ostatnich dawkach strawność tłuszczu była ujemna. Największe różnice między współczynnikami strawności stwierdzono przy skarmianiu zielonki.

Odzyskanie ligniny w kale wahało się od 98 do $101 \%$ przy skarmianiu dawek złożonych z ziarna i siana lub samego siana, a tylko $87 \%$ przy podawaniu zielonki. 